\title{
Shamrock Aborigines: the Irish, the Aboriginal Australians and their children
}

\author{
Ann McGrath
}

\begin{abstract}
'Shamrock Aborigine' is the sentimental nickname to denote Aboriginal Australians with Irish descent. The Shamrock's green, round-leafed trinity has become a national and religious symbol of Irishness, associated with both Saint Patrick and good luck. This humble wild plant suggests closeness to the earth and a grounded sense of place. As a signifier for a rural people, it also evokes many intangible so-called national characteristics such as a quirky sense of humour, a cherished memory of magical creatures or faerie, a storytelling 'gift of the gab' and a love of emotive ballads. ${ }^{1}$ Moree's Aboriginal rugby team is called the 'Shamrock Aboriginal Warriors'. ${ }^{2}$ They wear green, white and a shamrock emblem. Earlier clues that Aboriginal people may have adopted the emblem include an 1890s nulla nulla with a shamrock carving. From the tablelands district of New South Wales, it is now held in the Australian Museum. ${ }^{3}$ Some contemporary Darug people believe their ancestors intermarried with the Irish to provide immunity from the near-devastating contagion of smallpox. ${ }^{4}$ In January 2009, controversial commentator Andrew Bolt used Mick Dodson's Irish ancestry to question his assertions of an 'Aboriginal' identity. ${ }^{5}$ Dodson, the 2009 Australian of the Year, replied that he had not had to fight racism due to his Irish ancestry. ${ }^{6}$
\end{abstract}

In August 2009, the newspaper Irish Echo published a list of the top 100 Irish Australians. This included bushranger Ned Kelly, the former Prime Minister Kevin Rudd, Aboriginal singer Kev Carmody and Aboriginal athlete Patrick Johnson. ${ }^{7}$ While yearning for ancestral stories may be a common human trait,

1 Reece 2000: passim.

2 Norman 2006: 185.

3 Patrick and White 1994. Before jumping to conclusions, however, I note that a native clover plant liked by grazing animals has also been referred to as a shamrock, so this object requires more research. I also wonder whether the image may have come from playing cards, as a heart is also featured. Despite my doubts, the example remains intriguing and is listed as a shamrock in the museum's collection.

4 ABC Radio National, Morning Program, 23 February 2010.

5 Andrew Bolt, 'Myths made and rewarded', Herald Sun, 26 January 2009, accessed 23 March 2010: <http:/ / www.answerbag.com/article/Myths+made+and+rewarded/9f15a39a-7de9-0587b30b-de83da0521b4/rewarded>

6 Dodson, Mick, pers comm, mentioned in Keynote AIATSIS Conference, Canberra, 29 September 2009.

7 'Top 100 Irish Australians', Irish Echo, 29 July 2010, accessed 31 October 2010: <http://www. irishecho.com.au/category/immigration/heritage/top-100-irish-australians> 
descendents of New World immigrants have turned the quest for Irish relatives into a favourite hobby. As if the roots of Irish-born Australians have not sunk deeply enough into their settling soil, they seek a sense of belonging from more ancient histories with deeper connections to place. ${ }^{8}$ For different reasons, people of Irish-Aboriginal descent are also becoming increasingly interested in their Irish ancestry.

Little research has been conducted on the relationships between Irish immigrants and Aboriginal Australians, or how Irish and Aboriginal peoples and their descendents have envisaged their relationship. By revisiting the work of the leading Australian historian Patrick O'Farrell (1933-2003), this article will reconsider his influential assertions and suggest directions for further work in the field. This article then considers why the offspring of Irish and Aboriginal parents and their descendents currently appear more willing to publicly entertain Irish ancestry and family associations than do the offspring of other European ethnic groups. It questions commonly held assumptions about the Irish and Aborigines, especially contemporary historical memory of sexual and marital intermixing. It also considers earlier assertions that the Irish were 'good colonisers' in Australia, or at least, were comparatively more benign colonisers than the Scots or English.

From the earliest convict intrusions onto Aboriginal soil, heterosexual unions and intermarriage took place between Aboriginal people and Irish - usually between Irish men and Aboriginal women. Aboriginal mothers and some Irish mothers produced offspring with Irish-Aboriginal identities. Early Irish arrivals to Australia were predominantly working class, including opponents of British rule in Ireland, and free immigrants. Forced convict transportation ${ }^{9}$ and in later years, extensive poverty-propelled immigration, brought them to Australia. Such historical experiences created Australian Irish identity narratives forged out of centuries-long histories of British imperialism. Many of the Irish at home had lost their land, freedom of movement and rights to govern, while population policies known as 'plantation' served to outnumber the Catholic Irish with Protestant English. While many Irish emigrants improved their fortunes in Australia, others certainly suffered more hard times, with mantras such as 'the luck of the Irish' and a plethora of sad ballads and stories echoing poignant historical memories. ${ }^{10}$

\section{Connecting hemispheres}

Irish Australian ethnic identity has generally been associated with a common history of settler whiteness, which is the colour of coloniser power. While the Irish were certainly a 'founding people' in the story of white Australia, these founding moments also served to position Australia as a new locale for

8 Read 2000

9 Reece 1991.

10 Campbell 2008; O’Brien 2008: 150-166; Reece 2000. 
continuing conflicts over the British domination of Ireland, with a proportion of Irish convicts being punished as rebels against British rule. Furthermore, the majority Catholic Irish arguably became 'white Indigenous', promoting themselves as 'true Australians' as opposed to the 'British' fellow-colonists. ${ }^{11}$ While retrospectively the Irish are now normalised and homogenised as part of the group known as 'white pioneers', there remains great ambivalence, if not deep contradictions, regarding the place of the Irish in what is labelled the British colonising project. ${ }^{12}$ We must not forget that at least 20 per cent of the Irish immigrants to Australia were Protestant. These were more likely to be middle and upper class, and some were inclined to more closely identify with Englishness and Britishness over Irishness.

Immigrant journeys from the 'Old World' to the 'New' span hemispheres and centuries. Amateur family histories and other publications have conceptually linked the chains of Irish poverty and oppression with the chains of convict transportation to Australia. American historian Richard White explored his Irish roots in Remembering Ahanagran, a book that became a meditation on uprooted yet continuing memory. Several books explore Irish Australian family histories. Australian novelist Christopher Koch's The Many Coloured Land: an Irish memoir described travels in Ireland that linked him with an Irish convict ancestor transported to Tasmania. ${ }^{13}$ For many, Irish Australian journeys provide opportunities for a more introspective, familial or ancestrally-connected kind of identity tourism. As demonstrated by Oliver MacDonagh writing TheSharing of the Green: a Modern Irish History for Australians, the concept of diaspora allows for more than one homeland. ${ }^{14}$

To complicate this, however, in the last decades of the twentieth and during the twenty-first century, Australians of Aboriginal descent are also publicly identifying as Irish and some have journeyed to connect with Old World places and people. Indigenous Australian participants have performed their music, song and storytelling at Celtic festivals in various parts of Ireland, as well as in Brittany, France. As Aboriginal art gains an international following, Indigenous artists and art exhibitions have toured various Irish cities and towns. When visiting the Country Clare museum in Ennis in 2007, I noticed Aboriginal art for sale in the entrance to the old town centre building. Deeper inside was an exhibition on the great migration of Clare's population to the New World. In 1990, during the very early phase in the commercial Aboriginal art movement, Kathleen and Temerre Petyarre travelled to Dublin to open an exhibition at the Royal Hibernian Academy in Dublin. The significant Robert Holmes a Court collection of batik was entitled Utopia - A Picture Story after their own cattle station country. These artworks, which travelled to Limerick and Cork galleries, depict deep personal connections with 'country' as Indigenous people call their traditional lands in English, which include places of ancestral

11 The anonymous assessor assisted with some of these insights.

12 See Walter 2000.

13 Koch 2008. Bergin 2000 is a self-published example.

14 MacDonagh 1996. 
dreaming journeys. An Australian historian attending this event, Bob Reece, described Gaelic poetry readings that promoted a 'natural, indeed a primeval, cultural bond between Irish and Australian Indigenous peoples' - an 'HibernoAustralian indigenality' ${ }^{15}$ Whatever the different players make of such travels and exchanges, this Aboriginal Australian and Irish nexus is starting to reroute the old migration and historical itineraries. ${ }^{16}$

\section{Assimilators?}

So what is the explanation for this relatively congenial and increasingly connected relationship between Irish and Aboriginal roots? In his influential tome, The Irish in Australia, historian Patrick O'Farrell argued that the assimilationist tendencies of the Irish in Australia set them apart from Irish immigrants elsewhere. Unlike the Irish who migrated to the United States, they did not form ethnic enclaves. This was partly due to their willingness to speak English, but more so due to their practice of intermarrying with Scots, English and Welsh. These patterns led to social assimilation and integration into the wider Australian community. ${ }^{17}$

Patrick O'Farrell's observations on the subject of Irish/Aboriginal interactions have been particularly influential. O'Farrell had stated:

Relations between the Irish and Aborigines were generally of the kind indicated by the Aboriginal writer Faith Bandler, recalling her childhood in northern New South Wales. In contrast to Protestant paternalist or exploitative whites, Irish Catholics treated the Aborigines as human beings, as equals... ${ }^{18}$

Bandler, however, was not Aboriginal. She based her popular book Wacvie upon her father's story as a Pacific Island indentured labourer. ${ }^{19}$ Although O'Farrell placed his own comments in parenthesis - almost as an aside - he went on to extend his intermarriage hypothesis beyond British integration. Indeed, O'Farrell daringly argued that the Irish were not as sexually exploitative as other ethnic groups. Further, the Irish viewed Aborigines with:

[A]n equality extending to marriage, as distinct from the sexual exploitation common in white relations with Aborigines: the 'shamrock/ Aboriginal' names prominent among contemporary Aboriginal activists testifies to that relationship. ${ }^{20}$

15 Reece 2000: 192. See also Brody 1990.

16 Reece 2000: 193. He notes the actions of Irish Australians such as Paul Keating. Keating was the first Prime Minister to acknowledge historical wrongs in the Redfern Speech, and he brought in native title legislation.

17 Ignatiev 1995; O'Farrell 1987; Walker 2007: 267-282; Ward 1958; White 1981.

18 O'Farrell 1987: 72; Swain 1995. Reece 2000 admirably covers many aspects of this topic.

19 As an activist in Aboriginal rights struggles during 1960s, Bandler's dark complexion and strong identification with the Aboriginal rights movement, led others to make the same error. See Lake 2002; Bandler 1977, 1983.

20 O’Farrell 1987: 72. 
In other words, the Irish were the group more likely to cohabit with, acknowledge and rear children with Aboriginal women. These comments have crucial relevance to the wider history of British colonialism in Australia. It is difficult to know whether O'Farrell was simply echoing a more widely held belief, following a personal hunch, or whether he had gleaned more solid knowledge from his extensive historical readings.

So we need to look at the only supporting evidence he cites: surnames. While 'shamrock Aboriginal' names may now be common, Irish surnames provide neither proof of an Irishman's paternity, nor public recognition of their children. Under the new colonial and state administrations, a 'surname' was required for records of such things as blanket handouts, the census and general identification. Aboriginal people spoke their own languages and practiced complex naming protocols according to age, kin, events and other factors, but none involved patrilineal 'surnames'. Initially it was the police or officials who were required to enter 'sur' names in their records, but sometimes the Aboriginal mothers volunteered suitable names. Children of mixed Aboriginal and other descent were often named after their employers - and sometimes this, too, was an actual indication of the likelihood that these could be the actual biological fathers. Adults were also commonly named after the stations on which they lived. In various jurisdictions, the local police - many of Irish stock - collected the census data. They allocated their own names to local Aboriginal people for official purposes. Or so they said. ${ }^{21}$ Although they did not openly acknowledge or rear them, many such policemen biologically fathered children to Aboriginal casual or long-term partners. Cohabiting with Aboriginal women carried a social stigma amongst the coloniser community. By the turn of the nineteenth century, and the first half of the twentieth century in Queensland, Western Australia and the Northern Territory, it was illegal for white men to cohabit with Aboriginal women and they had to seek special permission to marry them..$^{22}$ Many of the male partners permitted to marry under state law were not so much prompted by egalitarianism as by the threat of large fines and imprisonment. ${ }^{23}$ For many, however, it took courage to openly declare these illicit partnerships and to try to keep families together, which some did.

O'Farrell's other assertion that the Irish were less paternalistic and exploitative, and were essentially egalitarian towards the Aborigines, must be viewed with caution. It would be extremely difficult to substantiate this from an empirical survey. How does one assess benevolence versus malevolence on the frontier? Possibly a scholar could revisit massacre statistics and try to research proportionately how many murders were committed by Irishmen and women, but due to the nature of the sources, this would be highly problematic, if not impossible. Furthermore, the intimate, often hidden sphere of sexual and familial relations is frequently missing from the archival record.

21 McGrath 1987: 68-94.

22 Grimshaw et al 1994; McGrath 1987.

23 McGrath 2003, 2005. 
Although travellers themselves, many of the early Irish Australians held unflattering notions of semi-nomadic and travelling people. They had been internal migrants in Great Britain, convict deportees and free immigrants whose single men became highly mobile workers travelling around the countryside. Newcomers alienated from their own country had plenty to fear from the Aboriginal people whose lands they were usurping. When convicts ventured onto the lands of Aborigines, they lacked armed protection, and it was hardly surprising they were at first terrified by the strangers. (In contrast, the more highly educated, intellectually curious and military-backed governors such as Phillip and Macquarie could sometimes afford to be more humane and tolerant.) $)^{24}$ Some Irish convicts had a bad reputation. In the early nineteenth century, the London Missionary Society's Lancelot Threlkeld reported horrific incidents of rape, robbery and general ill-treatment of Aborigines by 'croppies' or escaped convicts living as bushrangers or outlaws. ${ }^{25}$ Members of a convict underclass could be more likely to be cruel to their social inferiors, being under greater direct threat from them. Yet, co-operation and collaboration could ensure their survival; a peace could be made between Aborigines and Irishmen and women who formed relationships of mutual dependence. Immigrants keenly sought Aboriginal women for sexual and marital partnerships, especially so, given the disproportion of immigrant men in the frontier districts.

Yet, some accounts of Irish colonising anxiety are disturbing. ${ }^{26}$ Pastoralist Alexander Crawford, an Ulster man who had moved onto Aboriginal lands in what is now the Murchison district of New South Wales, was one of the better off, Protestant immigrants from Ireland. O'Farrell's collection of letters awkwardly placed Crawford's correspondence in a section entitled 'Love Story'. Yet Crawford's neighbours called him a tyrant because, unlike other masters, he would not allow the white men working on his station to 'keep black women' there. ${ }^{27}$ Crawford was neither egalitarian nor likely to marry an Aboriginal woman. However, perhaps in expressing his distaste for such mixed liaisons, he protested too loudly.

Crawford was certainly involved in violent captures and cruelties towards Aboriginal men killing sheep, and in May 1883, Aboriginal people nearly killed him in retaliation. ${ }^{28}$ Back in Ireland, Crawford's family were appalled at having a relative on a murdering rampage. His father foresaw more trouble, warning in his charming style:

I hope you are getting on with the natives better, your Aunt Matty says kindness goes far with them. Probably if you tried some of this you might do better. But I am sure you are kind naturally, yet you are too

24 Clendinnen 2003; O'Brien 2008.

25 Cited in O'Brien 2008: 156; Reece 1998; Stratton 2004.

26 O'Farrell 1984.

27 Alexander Crawford, cited in O'Farrell 1984: 71.

28 Cited in O'Farrell 1984: 73. 
much inclined to drive men more than lead. But most likely your views on this point may have been modified before now. My mother used to say never use the broken reed if love will do the deed. ${ }^{29}$

Letters from Lillie Mathews ridiculed him for not learning enough of the local Aboriginal language to be understood. ${ }^{30}$ Another violent skirmish on the property thwarted Alexander's marriage plans to this beloved Australian-based cousin. If only he had listened to Aunt Matty's pointed advice, he might have married her sooner.

With Crawford still seeking vengeance against Aborigines for taking his sheep, Lillie wrote on Sunday to admonish him:

It is a dreadful thing to be continually hunting down ones fellow creatures, for they are our fellow creatures and have precious and immortal souls. Oh my darling keep your hands free from your fellow creature's blood. For you to need to fire on them makes me feel miserable. It seems dreadful when really in your heart you cannot blame them for taking the sheep. They don't know right from wrong. ${ }^{31}$

Lillie tried to remind Crawford of the common humanity of the Aboriginal people:

We are, I know, apt to look down on them as something little better than beasts, but remember darling they have souls as well as we, and don't let them rise up in judgement against $u$ s in the last great day. ... Oh my darling keep yourself free from any stain of these poor creatures. ${ }^{32}$

Alexander's Irish-based Protestant relatives feared his Australian experience had not only corrupted him personally, but that it might endanger the souls of his entire family. They and the Australian-based Lillie were worried as Christians, seemingly less concerned about Alexander's safety than their own immortal fates.

The majority group, the Catholic Irish, suffered racism in nineteenth-century Australia and were derogatively compared with Aboriginal people. ${ }^{33}$ Contemporary commentators like Dr A Thompson asserted that the Irish were intellectually inferior to the Australian Aborigines. Pastor Samuel Marsden classed the Irish convicts as a 'wild, ignorant and savage Race' ${ }^{34}$ Others stated that the Irish were 'pre-modern, pre-industrial, their very existence superseded by progress, commerce, science, invention, the arrogances of the nineteenth century: like the Aborigines, the Irish were primitive, backward, outmoded,

29 James Wright Crawford, cited in O'Farrell 1984: 74.

30 Elizabeth Jane (Lillie) Mathews, cited in O'Farrell 1984: 79.

31 Elizabeth Jane (Lillie) Mathews, cited in O'Farrell 1984: 76.

32 Elizabeth Jane (Lillie) Mathews, cited in O'Farrell 1984: 79, my emphasis.

33 O'Farrell 1984: 72.

34 The Irish Catholics also did a lot to discredit Marsden. 
the butt of impatience and contempt'. ${ }^{35}$ Going further, the Irish were equated with chimpanzees and orangutans and ridiculed as of 'africanoid' appearance. ${ }^{36}$ Although the Scottish were also considered lowly, the Irish were consistently rated as inferior to them too. ${ }^{37}$ Throughout much of nineteenth- and twentiethcentury Australia, Anti-Irish and anti-Catholic thinking reinforced social, class and political divisions.

\section{Disentangling colonising colours}

Whiteness studies has analysed the power of the category ' white', ${ }^{38}$ which became especially relevant in the context of settler-colonialism. ${ }^{39}$ However, 'whiteness' needs to be carefully historicised in different periods and contexts. Historian Don Watson demonstrated how the Caledonians or Scottish highlanders were classed as 'black' and compared with 'Aborigines'. ${ }^{40}$ American author Noel Ignatiev's How the Irish Became White dramatised this in race and labour relations and identity studies. ${ }^{41}$ Jon Stratton argued that by the 1880 s, the likes of influential federationist Alfred Deakin needed to recast the Irish as 'white' as part of a homogenised sense of an Australian race and future 'white' nation. ${ }^{42}$

Empowered by their imperial status, settler colonisers had stakes in differentiating themselves from Indigenous Australians. After all, they were in the process of usurping them from their land. While the term 'Anglo-Celt' indicated cultural fusion, it could also suggest greater unity and common purpose than actually existed in the colonies at any specific historical moment. Initially, according to $\mathrm{O}^{\prime}$ Farrell, some of the Irish immigrants in nineteenth-century Australia spoke a different language to the English, Gaelic and most sounded different to the English, not only in accent and intonation, but in the way they expressed themselves and thought. They saw themselves as ethnically distinct and they were predominantly Catholics rather than Protestants. ${ }^{43}$ While some may have shared a specific identity, and dressed and looked different, the convict label saw Irish and English lumped together wearing similar attire. Although race categories were fluid in the first half of the nineteenth century, and living and working alongside each other could lead to rapid cultural fusions, according to $\mathrm{O}^{\prime}$ Farrell, Irish distinctiveness sometimes saw them as more than just an 'ethnic sub-group' of Britishness or a mere faction of the white colonisers. What $\mathrm{O}^{\prime}$ Farrell's generalisations sometimes gloss over, however, are the class differences, and the 20 per cent of Protestant Irish hailing from many different parts of Ireland, some of whom were prominent and wealthy citizens of influence.

35 O'Farrell 1984: 72.

36 Stratton 2004: 230-232.

37 Watson 1997.

38 Moreton-Robinson 2004.

39 See Lake and Reynolds 2008.

40 Watson 1997.

41 Campbell 2008; Ignatiev 1995.

42 Stratton 2004: 233-235.

43 O'Farrell 1987: 17. 
By giving so much attention to 'skin', the whiteness studies umbrella could further homogenise 'race' and ethnic categories, missing the significance of class, ethnic, religious and national identities. ${ }^{44}$ For example, Chris Healy's From the Ruins of Colonialism: History as Social Memory does not contain a single index entry on the Irish. ${ }^{45}$ Historian Ann Curthoys' important article, 'Expulsion, exodus and exile in white Australian historical mythology' fuses Anglo and Celt into one group. She explains how Australian coloniser narratives emphasise histories of expulsion and exile, ${ }^{46}$ a strategy that enabled them to see themselves as victims and to avoid being guilty 'colonisers' at all. While Curthoys' repeated references to 'Anglo-Celt' narrative strategies accurately reflected fused national narratives, surely it would be worth disentangling and effectively probing the specific development and influence of Celtic or Irish strategies. As Bob Reece's 1991 study, entitled Exiles from Erin: Convict Lives in Ireland and Australia suggests, the Irish have understood themselves as colonialism's victims in quite distinctive ways. ${ }^{47}$ Perhaps renewed emphasis is now required not only on the difference of the Asian, Pacific and other ethnic groups that settled in Australia, but on difference amongst the British colonisers in various timeframes. ${ }^{48}$ Only by separating the strands of 'Anglos and Celt' can historical studies of colonialism and memory tease out Irish from other influences.

Recognising the significance of the Irish to Australian Labor Party and trade union history, Prime Minister Bob Hawke launched O'Farrell's monumental The Irish in Australia in 1988. No fan of Aboriginal land rights or symbolic recognition of Aboriginal oppression, O'Farrell saw Aboriginal oppression as part of a longer historical trajectory of oppression by Britain. As he entertained no hopes for the indigenous Irish regaining lost lands, he entertained no hopes of special entitlements for the Aborigines. While $\mathrm{O}^{\prime}$ Farrell recognised the complexity, divisions, the different historical memories and the conflicting 'fairytales' amongst his chosen subjects, his was a sentimental, nationalistic mission to provide a fond and humane account of the Irish in Australia. He wrote eloquently: 'At any time, these were ambivalent, ambiguous people, thinking Irish, talking English; hating the tyranny, serving the tyrant ${ }^{\prime}{ }^{49}$ His Irish were a flawed lot. But for him to go further - to feature them as Godless, immoral sexual exploiters, or indeed violent colonisers themselves, was personally abhorrent. Not only would it do his ancestors too great a disservice, it would equate them too much with the English.

In the twentieth century, many Irish men, like other poor whites, travelled to northern frontier districts to make a living. Drover Matt Savage told a story of an Irish cook Mick Sharkey who eked out his subsistence by killing Aboriginal people's dogs around Bradshaws Run in the Victoria River District in the

44 Dyer 1997; Edwards and Yuanfang 2003; Hage 1998; Hokari 2003: 85-101; Moreton-Robinson 2004; Riggs 2007.

45 Healy 1997.

46 Curthoys 1999: 1-18.

47 Lake and Reynolds 2008; Reece 1991.

48 This has also changed in recent times, as attested by autobiographical writing like Kinnane 2003.

49 O'Farrell 1987: 5. 
1910s; a bounty on scalps netted good cash returns. When an angry group of local Aboriginal people confronted him, brandishing clubs, he started weeping, lamenting his loneliness and his distance from his homeland, and blubbering in fear that they would kill him. Before very long, the local Aboriginal people were weeping in sympathy for the poor displaced national. As the story goes, they then helped him obtain the scalps of a few more 'useless dogs'. ${ }^{50}$

The Irish, and historians of Irish descent, as well as the Aboriginal people they encountered, were all keen to find agreeable narratives. Whilst some may have appreciated the benefits of a more fluid Australian society and perhaps even thanked the monarch who presided over it, the Irish brought a range of stories of British imperialism to Australian shores, and distinctly Irish nuances soon appeared early in colonising narratives. Accepting that intermarriage between Anglo and Celts justified identity fusion, Irish descendents still had strong historical and emotional reasons to discretely identify themselves as colonialism's exiled victims. The shared oppression of the Aboriginal and Irish people by the British gave them common historical ground as the 'colonised' class - even if they ended up later fighting over the same Australian ground, and the same Aboriginal women.

\section{The children}

Since the publication of the Bringing Them Home Report in 1992, the topic of Australia's 'stolen children', or the removal of children of Aboriginal and of Aboriginal and mixed descent from their Aboriginal families, has gained considerable attention. ${ }^{51}$ Labor Prime Minister Kevin Rudd's Apology in Parliament in February 2008 became a national moment of recognition for the historical suffering of Indigenous Australians. ${ }^{52}$ The Report itself contained horrendous stories of cultural loss, emotional and familial damage. Until the 1970s in New South Wales, the Northern Territory, Western Australia and elsewhere, Aboriginal children and particularly those of mixed descent were removed from their parents.

While generally we imagine that removal severed Aboriginal people away from their Aboriginal families, child removal also severed them from many of their Irish, English and Chinese fathers and occasionally, from their Irish mothers. It severed them from immigrants who returned to Ireland. In the burgeoning field of autobiography of the 2000s, numerous people of Aboriginal descent now refer to their mixed European, Asian and family backgrounds. Some have also pursued their family histories in England, Europe and China..$^{53} \mathrm{New}$, reflexive Indigenous narratives interpreting colonising history also continue to emerge.

\footnotetext{
50 Willey 1971: 17-18.

51 Haebich 2000; Read and Edwards 1989.

52 Haebich 2000; Kevin Rudd's apology motion, cited in ABC News, 'The Apology', accessed 22 September 2008: <http:/ /www.abc.net.au/news/events/apology/>

53 Ah Kit 2003: 115-123; Kinnane 2003; Martiniello 2003: 23-35.
} 
In the intimate unions between Irish and Aborigines that followed the convict arrivals from distant Britain after 1788, at least two histories of colonialism met, with complex and fraught historical legacies. The ambiguous status of the Irish in the British colonising project contained challenges for the children of Irish and Aboriginal parents. In the sexual and familial relations between Indigenous and Irish Australians, and in the generations that followed, the categories 'invader' and 'invaded'; coloniser and colonised become unstable. ${ }^{54}$ However hapless they might see themselves, Irish Australians formed a large chunk of Australia's 'settlers' or colonisers, and there could be no getting away from being implicated in dispossessing Indigenous Australia. When the Irish tried to fuse an older historical identity as an oppressed people, with a new one in which they were labelled oppressors, a narrative rupture arose.

Whether poor or wealthy, many Irish fathers found child removal a useful tool to hide their secrets and sins.$^{55}$ Policies varied between different colonies and states, and in northern Australia during the twentieth century, such unions were legally restricted. However, the known cases suggest that married Irish Catholic pastoralists were as likely as other colonisers to banish the offspring of their Aboriginal mistresses. Many were simply shirking financial responsibility. Some wealthy fathers paid for Catholic boarding schools, but that did not mean that they publicly recognised the child as their own offspring. (Over the past ten years, some of these children and grandchildren have come forward to tell their previously suppressed stories. $)^{56}$ If not improving heavenly prospects, colonial life provided opportunities for Irish men and women's economic and social advancement and status. Therefore, an additional reason for Irish men to keep their partnerships quiet was that any marriage with Aboriginal women, the class dispossessed of all land and property, would destroy prospects of social respectability.

If education in English, and intermarriage, were dual tools of ethnic assimilation, in this case, we have to ask who was assimilating whom - the English or the Irish? (While the influence of Indigenous culture and life-ways upon Irish and other immigrants should not be dismissed, there is not the extant research or the space here to assess this kind of cultural influence.) One of the government justifications for Aboriginal and mixed-descent child removal was certainly to provide literacy and western-style education. ${ }^{57}$ Here again, the Irish in Australia would empathise with their homeland situation, as English was often used in preference to Gaelic as the language of learning and of state, legal and religious authority. Keen to gain social mobility, Irish immigrants in Australia voluntarily opted to blend in with the general white population rather than asserting difference. Aboriginal people suffered a government- enforced cultural assimilation policy. During the post-World War Two era, Aboriginal assimilation aimed at cultural and economic 'uplift', yet racial discrimination against

54 Ellinghaus 2003, 2006; Haskins and Maynard 2005; McGrath 2005.

55 For a related article on paternity see Probyn-Rapsey 2009.

56 Haebich and Mellor 2002; Wilson 1997.

57 Van Toorn 2006. 
Aboriginal people and their offspring eroded many of the possibilities for social and economic advancement enjoyed by immigrants. ${ }^{58}$ Furthermore, immigrants often had prior knowledge of how to deal with displacements and relocations that took place in Britain. Amidst the state project of land take-over, Aboriginal people's ongoing desire and struggle to hold onto their lands often forced them into a direct oppositional relationship to the state.

What is more, due to discriminatory laws, policies and racial attitudes, throughout much of the twentieth century, many Aboriginal people sensibly avoided identifying as Aboriginal. Only after improved civil rights from the 1970s were more Aboriginal Australians of mixed descent wiling to positively identify and expose their families to the consequences. Identity politics then turned full circle. Aboriginal rights activists urged people of mixed descent to identify as 'Aboriginal' - and only Aboriginal. While the McGinness family of Darwin cherished their Kungarakany culture and were the first group to have their traditional land claim heard in the Northern Territory, Kathy Mills (nee McGinness) objected to being described as 'part Aboriginal' and not also as 'part European' or Irish. When she presented a paper to this effect at the 1980s Women \& Labor Conference in Melbourne, the audience was not yet ready for such multiple identities, ${ }^{59}$ but times are changing.

\section{The Irish's historical reputation}

Until the 1980s, Irish studies and Irish history in Australia represented a core strand in Australian historical study. Historians noted the large proportion of Irish convicts and their major role in forming the basis of the Australian population, ethos and nation. They explored their radical challenge to the English-led state, their roles in key rebellions, outlawry and other challenges to authority. Russel Ward's Australian Legend and particularly his chapter 'Celts and Currency' attributed Irishness as foundational to the evolution of an egalitarian, working class culture that morphed into a distinctive (white male) Australianness. ${ }^{60}$ The feminist historian Miriam Dixson's The Real Matilda took the shine off the masculinist legend, attributing Irish influence to many less admirable national characteristics, including Australia's drinking culture, and some of its sexist practices. ${ }^{61}$ More recently, historian Anne $\mathrm{O}^{\prime}$ Brien has reminded us out how, during the 1810s and 1820s, the Irish were feared as a threat to the British settlement. In the earliest convict settlements of the late eighteenth century, the English authorities even feared that the Irish would join ranks with the Aborigines and 'overtake the colony'. ${ }^{62}$

58 Haebich 2008.

59 The author convened this panel.

60 Ward 1958.

61 Dixson 1984.

62 Neil Gunson (ed) 1974, cited in O'Brien 2008: 156. 
With the rise of race relations and Aboriginal history studies from the late 1970s, ${ }^{63}$ the history of the Irish in Australia gradually came to be seen as less attractive: as white, masculinist and mainstream - as part of the dominant group of coloniser invaders. Worse, Aboriginal activists and historians started to discuss white men's rape and sexual exploitation of Aboriginal women. ${ }^{64}$ When the National Museum of Australia (NMA) opened in 2001 under the regime of Prime Minister John Howard, it was attacked for favouring the so-called 'black armband' view of Australian history and accused of exaggerating frontier violence and giving too much prominence to Aboriginal history over white. In this context, a proposal to stage an exhibition on the Irish, including their usual bunch of rebels and radicals, was comparatively reassuring, if not exactly 'relaxed and comfortable ${ }^{65}$ While this venture did not proceed, another is being planned. In 2002-2003, the museum staged an exhibition Outlawed!Rebels, Revolutionaries and Bushrangers, where none other could match the drawcard status of the national Australian hero Ned Kelly. Yet, Ned's Jerilderie letter was hardly inclusive, spitting out bitter, murderous and ever-colourful messages proclaiming ethnic Irish anger at English injustice. ${ }^{66}$

In the twenty-first century, popular blogs like that of Bob Gould keep alive both Irish nostalgia and a powerful desire for not only nationally redemptive narratives, but also ethnically-specific Irish ones. ${ }^{67}$ The 'Iron Outlaw' site on the Kelly gang contains many references to Irish oppression. ${ }^{68}$ As neither Marxist nor Aboriginal, Ned Kelly epitomised a cherished, albeit controversial icon where Irish anger has become generalised white Australian anger at English authority, class and state oppression.

\section{Heaven or Hell}

My own family's story is instructive on the selectiveness of Australian identity narratives, for we grew up thinking that we were Irish through and through. My Australian-born grandmother, Nana Morris, was indeed a Clancy of Irish stock. My grandfather was an Australian-born son of a Galway-born McGrath. My paternal grandmother, however, was Scottish-born and raised in Kirkintilloch until the age of 16 before immigrating. These Scottish Egans identified as both Irish and Scottish. Then, on my father's side, my great-grandmother was born illegitimate in Manchester. My maternal grandfather was Australian-born

63 Curthoys and Moore 1995: 1-29; Saunders and Evans 1992.

64 Saunders and Evans 1992.

65 The then Prime Minister John Howard stated that Australians should be able to feel more than shame and guilt about their history; rather they should feel 'relaxed and comfortable' about it. For a fuller examination of the History wars, see Macintyre 2003.

66 McDermott 2001.

67 Gould, Bob, 'The fate and future of Aboriginal Australians', in Ozleft, updated 7 April 2000, accessed 22 September 2008: <http://members.optushome.com.au/spainter/Fateandfuture. html>

68 'Ned Kelly Australian', updated 9 September 2008, accessed 22 September 2008: <http:/ / www. ironoutlaw.com/> 
of English Anglican stock. So, despite an English born great grandmother on one side, an English-born great grandfather on the other, and a Scottish-born grandmother, we were still 'Irish' and did not question why only our Irish roots were to be valorised. Like many other intermarried Australian families, our family was not exclusively Irish by birth or ethnic background, but we imagined ourselves as Irish. Essentially, Irish was our preferred identity.

Furthermore, the Australian Catholic Church, which ran a comprehensive system of primary and secondary schools around Australia, encouraged the love of Erin. Catholic-run Aboriginal missions in remote Australia, and powerful Australia-run Catholic school system in rural towns and cities spread the virtues of Irishness to white and black children. Their teachers were often from poor backgrounds themselves, and they often accepted children excluded from New South Wales government schools on the basis of Aboriginality and those unable to pay. ${ }^{69}$

During the 1950s-1970s, numerous nuns and priests had come from Ireland or were of Irish stock. ${ }^{70}$ The school and church system powerfully reinforced a collective Irish Australian identity from the earliest years, with its special Catholic school textbooks and publishers. In the 1960s, even the Australian-born nuns who taught me railed against the media practice of referring to the 'Roman Catholic church', for they insisted they were not Roman. If religion had to have a nationality, they would only settle for Irish Catholic. When I visited Ireland for the first time during the Settler Colonialism conference in 2007 I saw the same religious décor of my childhood's 1960s Australian churches, with an identical selection of pious and maternal Virgin Mary statues, celibate French saints like St Therese of Liseux and Sacred Hearts of both Jesus and Mary. ${ }^{71}$ Australian Catholic religious identity became a form of Irish identity.

Since the 1990s, the links between Australian Indigenous and Irish convict dispossessions have created new alliances between church and Indigenous communities. The Catholic Left was prominent in Reconciliation, native title, in organisations like Women for Wik, the stolen children campaigns and in inclusive Indigenous theological approaches and church services. In 2009, Aboriginal singer Archie Roach sang at a fund-raiser to stop the Catholic church's sale of St Brigid's church, which was established in the 1850s by victims of the famine who immigrated to Victoria. The common bond here was not common ancestry, for he has not associated with Irish identity, but rather, common dispossessions and enforced community ruptures. Roach is a Gunditjmara man and it was his traditional lands to which the famine refugees sailed, then settled and built that church. ${ }^{72}$

69 Goodall 1996; Mason 2008; Reece 2000. For a valuable comparative study, see Coleman 2007.

70 Catholicism also featured in mid-century politics, with a key split in the Labor Party and the formation of the Catholic-based Democratic Labor Party.

71 Campion 1987; Massam 1996.

72 The Standard, 22 June 2009, <http:/ / www.standard.net.au/news/local/news/general/selloutevent-raises-10000-for-church-lifeline/1546512.aspx>. See also Shane Howard with Regina Lane, 'Irish and Indigenous gathering places', Eureka Street, 2 July 2009, <Eurekastreet.com.au>. 
Over the last 15 years, historians of empire began to pay serious attention to intermarriage across colonising frontiers. ${ }^{73}$ 'Bodies in contact' created a key tension and anxiety for colonisers and empire. Intermixing and intermarriage was commonplace between non-Aborigines and British of various ethnicities from the early nineteenth century through to the present. ${ }^{74}$ Ellinghaus, Henningham, Haskins, Maynard, Hannah and myself have written on the subject. ${ }^{75}$ But, unless discussing 'Asians' and non-white 'others', these studies inevitably refer to Aborigines intermarrying 'white' men or women. To date, scholars have not singled out Irish intermarriage for special attention, nor considered its impact on dual identity formation.

Perhaps this is not surprising, as fact-finding about Irish/Aboriginal intermarriage is difficult. Firstly, who truly fits into the category of Irish? How are they identified as such? Do we include only Irish-born, or second or third generation? Is Irishness based on birthplace, culture, religion or parentage? If we accept the latter, is this born in Australia, or born in other parts of Britain outside of Ireland? Or could they also be born in America? Do both parents have to be Irish, or just the mother or father, or grandfather? What is the appropriate descent percentage? If it a matter of self-identification, that evidence is not available. Although colonial and later state regulations did create their own special marriage archives, it is difficult to quantify Irish unions with Aboriginal women and to measure the degree of acknowledgement of their children. Some archival repositories prevent the use of real names and recent scholars choose to obscure them for privacy reasons. Possibly the best evidence can only be gleaned from insider perspectives, when more Aboriginal people research their own family histories.

Traps abound for any researcher. For example, bush traveller and author Bill Harney (1895-1962) was one of a few white men who openly acknowledged and published accounts of his relationships with Aboriginal women during the first half of the twentieth century. His autobiography seems to fit O'Farrell's ideas about Irishmen's behaviours when partnering Aboriginal women. While known to have enjoyed numerous Aboriginal girlfriends, Harney had legally married the 17-year-old Aboriginal Kathleen Linda Beattie at Groote Eylandt chapel. Harney was a hard-living 'bush raconteur' of the irreverent kind glorified in the Bulletin and in Ward's Australian Legend. ${ }^{76}$ The fact that he found his Aboriginal nickname 'Bilarney' or 'Blarney' such a great joke led me to assume he was of Irish descent. The famous Blarney Stone of Ireland's Blarney Castle near Cork was a nice allusion to his penchant for story-telling. The Irish legend has it that whoever kisses the Blarney Stone acquires eloquence, or in local parlance, the 'gift of the gab'. The Blarney Stone has another twist - that of 'soft talk' meant to

73 Ballantyne and Burton 2005; Cooper and Stoler 1997; Stoler 2006, 1995.

74 McGrath 2005.

75 Ellinghaus 2006; Haskins and Maynard 2005; Hannah 2005; Henningham 1999: 61-70; McGrath 2005.

76 Harney 1957, 1958, 1961, 1963; Ward 1958. 
deceive without necessarily offending. ${ }^{77}$ The colloquial 'a lot of blarney' was used in Australia for a made up story, 'bullshit' or in Aboriginal parlance 'gammon' ${ }^{78}$ The 'blarney' legend mocks and scoffs its own promise, perhaps reflecting not only the Irish penchant for storytelling, but also a sense of humour and selfmockery the Irish had in common with, and enjoyed sharing with Aboriginal people.

Harney and his wife had children together during the 1920s and 1930s, but both his wife and the children died young. ${ }^{79}$ His child to another woman - this time to a Wardaman woman in the Katherine area in 1936, took the name Bill Harney, identifying as the author's son. Although similar to WEH Harney senior in appearance and character, he was not reared by him, but by his mother Ludi Yibuluyma and his Aboriginal stepfather. Bill is a renowned storyteller of Indigenous creation stories. ${ }^{80}$ Despite his liking for the 'blarney/billarney' appellation, Bill Harney senior may not have been Irish at all. Possibly he encouraged it as an attractive, suitable label for a roving bushman who rebelled against propriety. My assumptions about his Irishness were first thrown by a quick check of the Australian Dictionary of Biography, which stated his parents were London-born. Harney is both an Irish and an English name. However, it is also possible that the Harneys hailed from the 'London Irish', earlier displacements leading to their emigration. Even in a relatively well-known life, his story thus demonstrates some of the difficulties of identifying possible 'Irishness'. His namesake's story provides another example whereby a child, and perhaps the mother, adopted a surname to signify paternity, although the child was not raised or necessarily officially acknowledged by his biological father.

\section{Shamrock Aborigines}

Let us now turn to the prominent Australian Aboriginal people who have identified as Aboriginal Irish. My web-site survey of some contemporary Aboriginal identities reveals several high achievers now choosing to publicly identify as Aboriginal-Irish. Artist Kevin Dolman, a member of 'Artists in the Black', described himself as 'Aboriginal-Irish Australian'. His website states: 'His mother is from the Eastern Arrernte people of central Australia, near Alice Springs and his father is an Irish immigrant from Derry in Northern Ireland' ${ }^{81}$

77 Ireland, 2006.

78 The Macquarie Dictionary, 1981.

79 Harney 1961.

80 Harney and Drew 2004: 90-97; Harney with Tietjen, 'Origins of the Didjeridu in Wardaman Country', July 1997, accessed 22 September 2008: <http://www.didjeridu.com/wickedsticks/ voices/harney.htm>

81 'Members of Reference Group for Artists in the Black', accessed 22 September 2008: <http:// www.artslaw.com.au/AboutUs/AITBRefGroup.asp> 
Singer and songwriter Kev Carmody's web biography boasts his family's amalgamation of Irish and Murri oral history and storytelling traditions. ${ }^{82}$ Canberra-based Indigenous poet Jennifer Martiniello celebrates her mixed Chinese-Irish and Arrernte ancestry. Of her granddaughter, who excels at Irish dancing; she explained that she was '[b]orn to it, a natural' ${ }^{83}$ The web site entry for athlete Patrick Johnson describes him as Aboriginal/Irish. After his Yarrabah-based mother died in a car accident when he was quite young, he was brought up on fishing boats by his determined Irish-born fisherman father. ${ }^{84}$ His fellow athlete Kyle van der Kuyp states his ambivalence about the singularity of 'Aboriginal identity':

In an awkward way it feels well I might be getting profiled because I'm an Aboriginal. If I was just a normal, you know, normal white Australian guy, you know, would I have a profile, probably not. I want people to know Kyle and not Kyle who's Aboriginal Irish. No one asks me about Irish but I'm half and half. ${ }^{85}$

Indigenous-Irish identity could also be deployed to explain injustice. It was used to make political sense of the plight of Dawn Casey, founding Director of the National Museum of Australia. Although a government-appointed review had sung her praises, ${ }^{86}$ the conservative Howard government and its appointed Museum Council labelled her as too sympathetic to the so-called 'black armband' view of Australian history. ${ }^{87}$ Indigenous leader Professor Mick Dodson blamed racism. As his angry farewell speech was reported:

An emotional Prof Dodson, who heads the Australian National University's indigenous studies unit, referred to their shared AboriginalIrish heritage.

He described Ms Casey as an inclusive director who embodied the spirit of Aboriginal womanhood and centuries of Irish struggle.

'Perhaps if you were white and had a dick and were of Anglo descent, you would have been treated with greater decency,' Prof Dodson said.

'But then again, the Anglos haven't been about treating blacks or Irish with any decency.'

82 'Kev Carmody's website: biography', accessed 22 September 2008: <http:/ / www.kevcarmody. com.au/biography.html>. With Paul Kelly, Kev Carmody co-wrote 'From Little Things Big Things Grow' about the Gurinji walk-off, a strike backed strongly backed by Irish-Australian and other radical unionists and in which, as mentioned above, McGinness was prominent.

83 Martiniello 2003: 34.

84 Vincent, 'Australian sprinter Patrick Johnson breaks 10 second barrier', in The World Today, 6 May 2003, accessed 22 September 2008: <http://www.abc.net.au/worldtoday/content/2003/ s848491.htm>

85 Epstein, 'Aboriginal athletes facing added pressures', in The World Today, 28 February 2000, accessed 22 September 2008: <http:/ / www.abc.net.au/worldtoday/stories/s104046.htm>

86 Carroll et al 2003

87 Macintyre and Clark 2004. 
Prof Dodson's tribute was choked by emotion and interrupted by his tears. ${ }^{88}$

Indigenous historian Wayne Atkinson suggested numerous notable people not on my list, including artist John Moriarty, painter of the Qantas planes, the 'father of reconciliation' Pat Dodson, and the 'mother of reconciliation' Lois O'Donoghue, who was removed from her Aboriginal family while young. The self-identified category of 'Aboriginal Irish' in Australia is becoming a familiar one. Aboriginal-German, Aboriginal-Chinese and Aboriginal Japanese would be more likely to be used than those other British ethnicities. It is rare indeed to hear of anyone identifying as 'Aboriginal English', 'Aboriginal Scots' or 'Aboriginal Welsh'. Yet in several regions of New South Wales during the first half of the nineteenth century, unions between Scots and Aborigines, and the English, were not uncommon. ${ }^{89}$

When referring to 'shamrock/Aboriginal' activists, O'Farrell may well have been thinking of activists and unionists Jack and Joe McGinness and Gary Foley. The McGinnesses were prominent leaders in Darwin and nationally, arguing against restrictions on Aboriginal rights and citizenship..$^{90}$ With others, they helped propel the Gurindji's famous walk-off from Wave Hill during the 1960s which argued for land rights and equal wages, popularly seen as the beginning of the modern land rights movement. ${ }^{91}$ In June 1967, as President of the Federal Council for the Advancement of Aborigines and Torres Strait Islanders, Joe was also influential in the Referendum movement that fought for 'citizenship' to Aboriginal Australians. While pleased about the win, he was a great fighter for Aboriginal rights: Val and Vai McGinness proudly continued the fighting spirit that they identified as 'Irish'. Val stated that his father was born on a 'Dublin ship' in New York Harbour. ${ }^{92}$

Cheryl Buchanun, Lionel Fogarty and other activists were leading figures in the famous 1972 Tent Embassy established outside Canberra's parliament house. It is difficult today to fully appreciate the courage of these individuals in opposing the state, for Aboriginal and mixed descent people had been subject to an extremely oppressive history of discriminatory legislation, violent punishment, incarceration and removal. According to some of their children, it was their 'fighting Irish' fathers that gave the 'shamrock Aborigines' the gall to fight the English, and authority in general, whatever the consequences. ${ }^{93}$ Although a 'Hibernophile', in 1987, Burnum Burnum, the imposing Aboriginal man who

88 'Academics say racism behind museum director's demise', Sydney Morning Herald, 11 December 2003, accessed 22 September 2008, available from: <http://www.smh.com.au/ articles/2003/12/11/1071086203319.html>

89 Robyn Bancroft, pers comm 2009; Ellinghaus 2006; Vicki Grieves, pers comm 2008; Haskins and Maynard 2005; Reece 2000.

90 McGinness 1991; Ann McGrath, 1982, Interview of Valentine McGinness, Australia 1938 Oral History Project, sound recording, National Library of Australia.

91 Attwood 2003; Taffe 2005.

92 McGrath, 1982, Interview of Valentine McGinness, Australia 1938 Oral History Project, sound recording, National Library of Australia.

93 McGinness 1991. 
planted the Aboriginal flag on the white cliffs of Dover during the 1988 Australian Bicentenary Celebrations, sharply criticised the 'shamrock Aborigines' for the 'Irish anger' of their protest tactics. ${ }^{94}$ However, the Irish line is just as likely to be associated with survival strategies. The Indigenous story that Darug people married Irish to ensure smallpox immunity denotes historical agency that is congruent with the positive 'survival' theme of the 1988 Indigenous celebrations.

\section{Irish as the good colonisers?}

That many Indigenous Australians can claim some Irish ancestry does not necessarily prove the 'good coloniser' theory. As we have seen, there is little nineteenth century historical evidence available to back the contention that Irish or Irish Australians were historically more likely than other ethnic groups to either marry Aboriginal women or rear their own children to them. Indeed, in the absence of evidence, it might well be 'blarney' ${ }^{95}$ In Queensland, Irish men were probably less likely to marry Aboriginal women than Asian and Pacific Islanders were.

Due to the problems of categorising 'the Irish', the quest is not only difficult but also misguided. We could fall into the same traps as the 1980s feminist historians who sought to measure whether 'white women' were less likely to be racist and violent than white men. The chimera of the 'good missus', the redemptive, wellbehaved coloniser has been debunked. ${ }^{96}$ Feminist and Indigenous historians have critiqued white women's repressive and often misguided complicity in 'rescuing' the 'colonised'. ${ }^{97}$ The prospect of any colonising group - whether analytically segregated on gender, class, ethnic or religious grounds - successfully maintaining the label of the 'good colonisers', therefore, seems like wishful thinking.

While the ruling English attract the blame for Australia's colonising cruelty, the Irish themselves were hardly blameless. Like men from English and Scots backgrounds, Irishmen were among the police, squatters, pastoralists and others known for corrupt and murderous behaviours against Aborigines. The police charged with removing the mixed descent children in Australia included many Irish-born or second generation Irish Australians. Amongst the 'good', downtrodden Irish fathers and humanitarian heroes were also plenty of violent and corrupt police, rapacious frontiersmen, timber getters and boat crew, unscrupulous and murderous squatters and dubious missionaries. ${ }^{98}$

Nonetheless, the Irish have fared well in some Indigenous narratives, including those of the North Australian Gurindji. These strongly support the 'good coloniser' as an Irishman myth - at least when it comes to Ned Kelly and a notion

94 Bone, 'Shamrock Aborigines', The Age, 30 September 1987; Reece 2000: 193.

95 Ronan 1954.

96 McGuire 1990: 124-151.

97 Haskins 2005; McGrath 1987; Paisley, Cole and Haskins 2005.

98 Seal 1996. 
that his country 'Island' was a good place. Unlike the Englishman 'Captain Cook' who travelled in the 'morally wrong' direction and thus did things the wrong way in regard to Aboriginal law, Gurindji stories feature a mythologised Ned Kelly who travelled across their country from 'Island' in the right direction, along the right song-line and on the 'good tracks' - all according to the prescribed Indigenous law of the country. ${ }^{99} \mathrm{He}$ would do good for them. The Gurindji must have heard about the legendary Irish Victorian, Ned Kelly, from white fellow stockmen or later unionists, some of whom were Irish or Aboriginal Irish such as Jack McGinness. ${ }^{100}$ In the Wave Hill walk-off, the Gurindji had to take on many authority figures: the managers, the British company led by Lord Vestey, the local managers and police. Ned Kelly may have inspired them to hold out in the bush with little food during the long 1960s strikes. The Gurindji did not believe people from afar arrived in their country accidentally, but rather, the earth, the land/dreaming had actually 'called' such people as Ned Kelly, author Frank Hardy and the radical Irish Australian trade unionists to travel there and assist in their fight for their land or country. ${ }^{101}$

Australians of all backgrounds embraced the embittered Irish Australian plotline of the Kelly legend. In becoming the iconic outlaw and national hero for all Australians, Ned Kelly transcended Irishness, yet Irishness remains intrinsic to his story. ${ }^{102}$ In Australian popular culture and labour history, Irishness came to be seen as a class and ethnic protest against English moral, class, political and 'race' superiority. Irishness has thus been successfully mythologised not only as a historical victimisation epic but also as a subversive anti-colonial and working class 'battler' identity. Not only did mainstream Australian colonial identities self-consciously distinguish themselves from the British in England, they embraced such 'Irish' values.

Whilst the Irish in Australia may have become 'assimilated' and the Australian people perhaps absorbed or were assimilated by Irishness, this did not lead the Irish to lose their cultural identity entirely. Nor is it surprising that when 'white' Irish descendents got to write their own history, they chose to be the 'good colonisers'. In the 1980s, O'Farrell's project distinguished the Irish from other settler colonisers. He selected culturally desirable moral markers of Irish difference (and superiority to the English). Indeed, the purported qualities of Irish Australian men remain morally appealing today: egalitarian, less racist, and, arguably more ethical as they recognised both their Aboriginal female partners and their children. No mention of violence, coercion, rape or murder. It was as if they were involved in a more benign, inclusive colonialism - as if without $\sin$.

99 Hokari 2001; Rose 1991; Nugent 2009.

100 Hardy 1968; McGinness 1991.

101 Hokari 2001.

102 Carey 2000; Seal 1996. 


\section{Shamrock Aborigines reconsidered}

The Australian hobby of travelling vast distances to find appealing Irish origin narratives is no longer the exclusive preserve of settler and migration identity quests. As with other Australians, the 'Aboriginal Irish' select from a range of potential ancestors. In addition, like other Australians, Aboriginal Australians of mixed ancestry would seem to prefer to identify as Irish rather than English. However blurred by collective nostalgia, Shamrock Aboriginal declarations represent a renewed agency around identity claims. They also remind us that, from the earliest generations, many Irish Australians were also Aboriginal Australians and vice versa. Through marriage, children and family, the Irish in Australia not only 'became white'; some also 'became black'.

With each Indigenous/ Irish Australian journey to connect with family histories of Old World dispossession, with each route connecting strands across the seas, aspects of settler colonialism's narratives can be read anew. However ephemerally, these journeys evoke the possibility of reverse journeys from the 'New World' to the 'Old'. Between hemispheres, and across complicated diasporas and older and newer histories of conflict and convergence, the diasporic kinship relations widen and complicate the genealogical charts.

When Aboriginal Irish venture back to Ireland, it is as though the origins journey is coming full circle: two old worlds, two deep pasts, converge in memory and imagination. Both the Irish and the Australian Aborigines have suffered histories of suffering, tragedy and resilience amidst deep troubles and mixed luck. They share a fighting spirit, a mischievous humour and an ability to create melodic and powerful stories. And they have more to share too. In 1999, an Aboriginal delegation travelled to Ireland on a trip to raise awareness of Indigenous issues. In the case of the Aboriginal Irish, subversive reputations, political strategies, and imaginative convergences and alliances flow between hemispheres. In 2002, Aboriginal leader Patrick Dodson visited Belfast on a reconciliation mission. As well as making statements in support of repatriation of Aboriginal human remains from European museums, he met up with a Protestant youth worker who grew up thinking that Catholics were 'the enemy'. A former Jesuit priest once excommunicated from the church, Patrick Dodson had brought a message of national Reconciliation. ${ }^{103}$

While the Irish are known for their affection to land, their 'love of Erin', with at least 50,000 years on the continent, Aboriginal Australians can certainly outdo anyone when it comes to deep roots and longevity in one land. In Ireland, hunter-gatherers only arrived about 8000 BC. However, the Irish outstrip Aborigines in the centuries they fought against British colonisation and shocking oppression. While cultural loss for Aboriginal Australians has been great, after decades of being defined and identified by others, the 'shamrock Aborigines' have consequently been creating anti-colonial but very 'Irish

103 Kimberley Land Council 1999; Irish Times, 16 October 1999, Weekend Australian, 16-17 October 1999. 
Australian' self-narratives. While Aboriginal-Irish identification may be deeply emotional, reflecting a desire for connection with close and distant kin, it serves another purpose too. By linking Indigenous Australia's 210-year-old history of oppression with an internationally known history that is at least two and a half centuries longer than theirs is, they gain layers of rhetorical and analytical clout. Furthermore, due to its distance, being removed on an island far away on the other side of the world, it is a history arguably more digestible to the wider Australian community. In partially displacing other histories of shame, but also connecting them, the Irish story is less psychologically confronting than Australian colonialism at home - a history in which their ancestors were complicit.

The intimate ties that bind Ireland, Irish Australia, Aboriginal Australia and Indigeneity include paternity, maternity, family and kinship. Australians of Indigenous and Irish ancestry not only literally change the complexion of these ancestral adventures, they also complicate their chronologies and re-imagine canonical narratives of power. Exiled sons become exiled fathers. Furthermore, they continue to create multiple and informative historical stories that connect distant worlds. Shamrock Aborigines draw strength from the appealing fit of Ireland's enduring histories of colonisation and displacement. In the latest travel itineraries, role reversals and fusions cannot be denied; the once colonised becomes the coloniser, the once Indigenous becomes the non-Indigenous.

\section{Acknowledgements}

I would like to acknowledge Wayne Atkinson and John Docker and the organisers of the Settler Colonialism Conference of 2007 and historian Malcolm Campbell for his encouraging advice. I thank Heidi Norman and JB Duncan for leads on the Shamrock Aboriginal Warriors Rugby League team. Above all, I would like to thank my former colleague at the University of New South Wales, Patrick O'Farrell, who died in 2003. Your writings inspired me, as did your encouragement at an early stage of my career.

\section{References}

\section{Archival sources}

McGrath, Ann 1982, Interview of Valentine McGinness, Australia 1938 Oral History Project, sound recording, National Library of Australia, Canberra.

\section{Newspapers \\ The Age \\ Herald Sun}


Irish Echo

Irish Times

The Standard

Sydney Morning Herald

Weekend Australian

\section{Secondary sources}

ABC News, 'The Apology', accessed 22 September 2008: <http:/ / www.abc.net. $\mathrm{au} /$ news/events/apology/>

'Academics say racism behind museum director's demise', Sydney Morning Herald, 11 December 2003, accessed 22 September 2008, available from <http://www.smh.com.au/articles/2003/12/11/1071086203319.html>

Ah Kit, John 2003, 'A Chinaman in the Woodpile or a Blackfella in the House', in Lost in the Whitewash: Aboriginal-Asian Encounters in Australia, 1901-2001, Penny Edwards and Shen Yuanfang (eds), Humanities Research Centre, Canberra, 115-123.

Anon 2006, Ireland, Lonely Planet, Melbourne.

Anon, 'Ned Kelly Australian', updated 9 September 2008, accessed 22 September 2008: <http:/ /www.ironoutlaw.com/>

Attwood, Bain 2003, Rights for Aborigines, Allen \& Unwin, Sydney.

Ballantyne, Tony and Antoinette Burton (eds) 2005, Bodies in Contact: Rethinking Colonial Encounters in World History, Duke University Press, Durham.

Bandler, Faith 1977, Wacvie, Rigby, Adelaide.

- 1983, The Time Was Ripe: a History of the Aboriginal-Australian Fellowship (195669), Chippendale: Alternative Publishing Co-operative, Sydney.

Bergin, Peter J 2000, Kilkenny to Buninyong: In and Out of Chains, Peter Bergin, Melbourne.

Bone, Pamela 1987, 'Shamrock Aborigines', The Age, 3 September 1987.

Brody, A 1990, Utopia: a Picture Story, 88 Silk Batiks from the Robert Holmes a Court Collection, Heytesbury Holdings Ltd, Perth. 
ABORIGINAL HISTORY 2010 VOL 34

Campbell, Malcolm 2008, Ireland's New Worlds: Immigrants, Politics, and Society in the United States and Australia, 1815-1922, University of Wisconsin Press, Wisconsin.

Campion, Edmund 1987, Australian Catholics, Penguin, Melbourne,

Carey, Peter 2000, True History of the Kelly Gang, University of Queensland Press, Brisbane.

Carroll, John et al 2003, Review of the National Museum of Australia, its Exhibitions and Public Programs: a Report to the Council of the National Museum of Australia, Department of Communications, Information Technology and the Arts, Canberra.

Clendinnen, Inga 2003, Dancing with Strangers, Text Publishing, Melbourne.

Coleman, Michael 2007, American Indians, the Irish, and Government Schooling, University of Nebraska, Lincoln.

Cooper, Frederick and Ann Laura Stoler (eds) 1997, Tensions of Empire: Colonial Cultures in a Bourgeois World, University of California Press, Berkeley.

Curthoys, Ann 1999, 'Expulsion, exodus and exile in white Australian historical mythology', Journal of Australian Studies 61, June: 1-18.

- and Clive Moore 1995, 'Working for the white people: an historiographic essay on Aboriginal and Torres Strait Islander labour', Labour History 69: 1-29.

Dixson, Miriam 1984, The Real Matilda: Woman and Identity in Australia 1788 to the Present, Penguin, Melbourne.

Dyer, Richard 1997, White, Routledge, London and New York.

Edwards, Penny and Shen Yuanfang (eds) 2003, Lost in the Whitewash: AboriginalAsian Encounters in Australia, 1901-2001, Humanities Research Centre, Canberra.

Ellinghaus, Katherine 2003, 'Absorbing the "Aboriginal problem": controlling interracial marriage in Australia in the Late 19th and Early 20th centuries', Aboriginal History 27: 183-207.

- 2006, Taking Assimilation to Heart: Marriages of White Women and Indigenous Men in the United States and Australia, 1887-1937, University of Nebraska Press, Lincoln.

Epstein, Rafael, 'Aboriginal athletes facing added pressures', in The World Today, 28 February 2000, accessed 22 September 2008: <http://www.abc.net.au/ worldtoday/stories/s104046.htm> 
Goodall, Heather 1996, Invasion to Embassy: Land in Aboriginal Politics in New South Wales, 1770-1972, Allen \& Unwin and Black Books, Sydney.

Gould, Bob, 'The Fate and Future of Aboriginal Australians', in Ozleft, updated 7 April 2000, accessed 22 September 2008: <http://members.optushome.com. au/spainter/Fateandfuture.html>

Grimshaw, Patricia, Marilyn Lake, Ann McGrath and Marian Quartly 1994, Creating a Nation, McPhee Gribble, Melbourne.

Haebich, Anna 2000, Broken Circles: Fragmenting Indigenous Families 1800-2000 Fremantle Arts Centre Press, Fremantle.

- 2008, Spinning the Dream: Assimilation in Australia, 1950-1970, Fremantle Press, Fremantle.

- and Doreen Mellor 2002, Many Voices: Reflections on Experiences of Indigenous Child Separation, National Library of Australia, Canberra.

Hage, Ghassan 1998, White Nation: Fantasies of White Supremacy in a Multicultural Society, Pluto, Sydney.

Hannah, Mark 2005, 'Constituting Marriage: Indigenous and Inter-Cultural Marriage and Power of "Protectors"', unpublished PhD thesis, Australian National University, Canberra.

Hardy, Frank 1968, The Unlucky Australians, Nelson, Melbourne.

Harney, WEH 1957, Life Among the Aborigines, Hale, London.

- 1958, Content to Lie in the Sun, Hale, London.

- 1961, Grief, Gaiety and Aborigines, Hale, London.

- 1963, The Shady Tree, Rigby, Adelaide.

Harney, Bill and Julie Drew 2004, 'A Wardaman Creation story by Bill Harney', Australian Aboriginal Studies 2 (September): 90-97.

Harney, Bill with Fred Tietjen, 'Origins of the Didjeridu in Wardaman Country', July 1997, accessed 22 September 2008: <http://www.didjeridu.com/ wickedsticks/voices/harney.htm>

Haskins, Victoria 2005, One Bright Spot, Palgrave Macmillan, New York.

- and John Maynard 2005, 'Sex, race and power: Aboriginal men and white women in Australian history', Australian Historical Studies 37(126), October: 191-216. 
Healy, Chris 1997, From the Ruins of Colonialism: History as Social Memory, Cambridge University Press, New York.

Henningham, Nikki 1999, “"Due consideration and kindness": interracial marriage in North Queensland, 1890-1920', in Citizenship, Women and Social Justice: International Historical Perspectives, Joy Damousi and Katherine Ellinghaus (eds), Melbourne University Press, Melbourne, 61-70.

Hokari, Minoru 2001, 'Cross-Culturalizing History: Journey to the Gurindji Way of Historical Practice', unpublished PhD thesis, Australian National University, Canberra.

Howard, Shane with Regina Lane, 2009, 'Irish and Indigenous gathering places', Eureka Street, accessed 10 August 2009: <www.eurekastreet.com.au>

Ignatiev, Noel 1995, How the Irish Became White, Routledge, New York.

'Kev Carmody's website: biography', accessed 22 September 2008: <http:// www.kevcarmody.com.au/biography.html>

Kimberley Land Council 1999, Report of the Visit to the UK and Ireland by a Delegation of Aboriginal Leaders Oct 1999, KLC, Kununurra.

Kinnane, Stephen 2003, Shadow Lines, Fremantle Arts Centre Press, Fremantle.

Koch, Christopher 2008, The Many Coloured Land: an Irish Memoir, Vintage Books, Sydney.

Lake, Marilyn 2002, Faith: Faith Bandler, Gentle Activist, Allen \& Unwin, Sydney.

- and Henry Reynolds 2008, Drawing the Global Colour Line: White Men's Countries and the Question of Racial Equality, Melbourne University Press, Melbourne.

MacDonagh, Oliver 1996, TheSharing of the Green: a Modern Irish History for Australians, Allen \& Unwin, Sydney

- and William F Mandle (eds) 1986, Ireland and Irish-Australia: Studies in Cultural and Political history, Croom Helm, London.

McDermott, Alex (ed) 2001, The Jerilderie Letter/Ned Kelly, Text Publishing, Melbourne.

McGinness, Joe 1991, Son of Alyandabu: My Fight for Aboriginal Rights, University of Queensland Press, Brisbane.

McGrath, Ann 1987, Born in the Cattle: Aborigines in Cattle Country, Allen \& Unwin, Sydney. 
- 2003, 'The golden thread of kinship: mixed marriages between Asians and Aboriginal women during Australia's Federation era', in Lost in the Whitewash: Aboriginal-Asian Encounters in Australia, 1901-2001, Penny Edwards and Shen Yuanfang (eds), Humanities Research Centre, Canberra.

- 2005, 'Consent, marriage and colonialism: Indigenous Australian women and colonizer marriages', Journal of Colonialism and Colonial History 6(3), Winter, available from: <http://muse.jhu.edu/journals/journal_of_colonialism_ and_colonial_history/v006/6.3mcgrath.html>

McGuire, ME 1990, 'The legend of the Good Fella Missus', Aboriginal History 14: 124-151.

Macintyre, Stuart and Anna Clark 2004, The History Wars, Melbourne University Press, Melbourne.

The Macquarie Dictionary, 1981, Macquarie Library, Sydney.

Martiniello, Jennifer 2003, 'As strands of plaited music: my Chinese-AboriginalAnglo heritage', in Lost in the Whitewash: Aboriginal-Asian Encounters in Australia, 1901-2001, Penny Edwards and Shen Yuanfang (eds), Humanities Research Centre, Canberra: 23-35.

Massam, Katharine 1996, Sacred Threads: Catholic Spirituality in Australia 19221962, UNSW Press, Sydney.

Mason, Robert 2008, 'The looming battle: Our Lady of Fatima and public space in Cold War Queensland', Journal of the Royal Australian Historical Society 94(1), June: 57-73.

Moreton-Robinson, Aileen (ed) 2004, Whitening Race: Essays in Social and Cultural Criticism, Aboriginal Studies Press, Canberra.

Members of Reference Group for Artists in the Black, accessed 22 September 2008: <http:/ / www.artslaw.com.au/AboutUs/AITBRefGroup.asp>

Norman, Heidi 2006, 'A modern day corroboree: towards a history of the New South Wales Aboriginal Rugby League Knockout', Aboriginal History 30: 169186.

Nugent, Maria 2009, Captain Cook Was Here, Cambridge University Press, Port Melbourne.

- 2008, "'Kitchen fragments and garden stuff": poor law discourse and Indigenous people in early colonial New South Wales', Australian Historical Studies 39(2), June: 150-166. 
ABORIGINAL HISTORY 2010 VOL 34

O’Farrell, Patrick 1984, Letters from Irish Australia, 1825-1929, UNSW Press.

- 1987, The Irish in Australia, UNSW Press, Sydney.

Paisley, Fiona, Anna Cole and Victoria Haskins (eds) 2005, Uncommon Ground: White Women in Aboriginal History, Aboriginal Studies Press, Canberra.

Patrick, Kathy and Peter White 1994, 'Australian Museum's Aboriginal Collections', Nulla Nulla, Northern Tablelands, New South Wales,

<http:/ / 66.102.1.104/scholar?q=cache:ZD6Sf9ekGgIJ:scholar.google.com/+sha mrock+aboriginal\&hl=en>

Probyn-Rapsey, F 2009, “'Uplifting” white men: marriage, maintenance and whiteness in Queensland, 1900-1910', Postcolonial Studies, 1466-1888, 12(1): 89-106.

Read, Peter 2000, Belonging: Australians, Place and Aboriginal Ownership, Cambridge University Press, Melbourne, available at: <http:/ / catalogue.nla. gov.au/Record / 204457?lookfor=author:(read peter)\&offset=13\&max=310>

- and Coral Edwards 1989, The Lost Children: Thirteen Australians Taken From Their Aboriginal Families Tell of the Struggle to Find Their Natural Parents, Doubleday, Sydney.

Reece, Bob 1991, Exiles from Erin: Convict Lives in Ireland and Australia, Macmillan, Basingstoke.

- 1998, 'The Irish and the Aborigines', Quadrant Magazine 42(1-2), January-February, available from: <http://www.thefreelibrary.com/ The+Irish+and+the+Aborigines-a020382693>

- 2000, 'The Irish and the Aborigines', in Irish-Australian Studies, T Foley and F Bateman (eds), Crossing Press, Sydney: 192-204.

- 2001, The Origins of Irish Convict Transportation to New South Wales, Houndmills, New York.

Riggs, Damien W (ed) 2007, Taking up the Challenge: Critical Race and Whiteness Studies in a Postcolonising Nation, Crawford House Publishing, Adelaide.

Ronan, Tom 1954, Vision Splendid, Cassell, London.

Rose, Deborah Bird 1991, Hidden Histories, Aboriginal Studies Press, Canberra.

Saunders, Kay and Raymond Evans (eds) 1992, Gender Relations in Australia: Domination and Negotiation, Harcourt Brace Jovanovich, Sydney. 
Seal, Graham 1996, The Outlaw Legend: a Cultural Tradition in Britain, America and Australia, Cambridge University Press, Melbourne.

Stoler, Ann Laura 1995, Race and the Education of Desire: Foucault's History of Sexuality and the Colonial Order of Things, Duke University Press, Durham.

- 2002, Carnal Knowledge and Imperial Power: Race and the Intimate in Colonial Rule, University of California Press, Berkeley.

- 2006, Haunted by Empire: Geographies of the Intimate in North American History, Duke University Press, Durham.

Stratton, Jon 2004, 'Borderline anxieties: what whitening the Irish has to do with keeping out asylum seekers', in Whitening Race: Essays in Social and Cultural Criticism, Aileen Moreton-Robinson (ed), Aboriginal Studies Press, Canberra: 222-238.

Swain, Shurlee 1995, Single Mothers and Their Children: Disposal, Punishment and Survival in Australia, Cambridge University Press, Melbourne.

Taffe, Sue 2005, Black and White together FCAATSI: the Federal Council for the Advancement of Aborigines and Torres Strait Islanders, 1958-1973, University of Queensland, Brisbane.

Van Toorn, Penny 2006, Writing Never Arrives Naked: Early Aboriginal Cultures of Writing in Australia, Aboriginal Studies Press, Canberra.

Vincent, Michael, 'Australian sprinter Patrick Johnson breaks 10 second barrier', in The World Today, 6 May 2003, accessed 22 September 2008: <http:/ / www. abc.net.au/worldtoday/content/2003/s848491.htm>

Walker, Brian 2007, “"The Lost Tribes of Ireland”: diversity, identity and loss among the Irish Diaspora', Irish Studies Review 15(3), August: 267-282.

Walter, Bronwen 2000, Outsiders Within: Whiteness, Place and Irish Women, Routledge, New York.

Ward, Russell 1958, The Australian Legend, Oxford University Press, Melbourne.

Watson, Don 1997, Caledonia Australis: Scottish Highlanders on the Frontier of Australia, Random House, Sydney.

White, Richard 1981, Inventing Australia: Images and Identity, 1888-1980, Allen \& Unwin, Sydney.

Willey, Keith 1971, Boss Drover, Rigby, Adelaide. 


\section{ABORIGINAL HISTORY 2010 VOL 34}

Wilson, Ronald 1997, Bringing Them Home: Report of the National Inquiry into the Separation of Aboriginal and Torres Strait Islander Children from their Families, Human Rights and Equal Opportunity Commission, Sydney.

Wolfe, Patrick 1994, 'Nation and miscegenation: discursive continuity in the post-Mabo era', Social Analysis 36, October: 93-152. 